\title{
Against the grain: segmenting and profiling irrigators opposed to water transfers in Alberta, Canada
}

\author{
K. C. Lafreniere ${ }^{1}$, H. Bjornlund ${ }^{1,2}$ \& S. Deshpande ${ }^{1}$ \\ ${ }^{1}$ University of Lethbridge, Canada \\ ${ }^{2}$ University of Southern Australia, Australia
}

\begin{abstract}
The growing demand for water in urban communities has increased pressure on current water entitlement holders, such as irrigators, to share their water. In the western Canadian province of Alberta, water sharing proposals often require irrigators to permanently sell their water. The majority of irrigation licenses are held by irrigation districts. Under the Irrigation District Act, the transfer of part of such licenses outside the district requires the approval of a majority of irrigators within the district. These water transfer plebiscites often attract considerable opposition from irrigators. Our study attempted to assess nature and reasons behind such opposition. Based on a survey of 275 randomly selected irrigators representing all districts of Alberta, we found that $40 \%$ of irrigators prefer sharing water rather than permanently selling it. Irrigators who oppose to water transfers belong to two groups. One group will always oppose water transfers regardless of any gains, while the other group considers factors such as environmental, personal or communal gains when they reject a water transfer. Strategies to effectively conduct a plebiscite on water sharing rights are later discussed.

Keywords: water transfer, natural resource management, water management, irrigation, irrigator preferences, water reallocation, Alberta, water scarcity.
\end{abstract}

\section{Introduction}

Southern Alberta faces tremendous water shortage that threatens to undermine population growth, economic development, and environmental balance. Water shortage requires better allocation of water resources among all users of the 
region. In response, in 2006 the Government of Alberta closed further licensing of three main river basins - Bow, Oldman and South Saskatchewan [1]. New water users must now obtain water licenses from existing users who gave up those rights [2]. Alberta Environment [3] anticipates further pressure on existing water users to share water, as the human demand for water in this area is projected to increase 20 percent by 2025 .

In this context, it is clear that sharing water resources is essential to accommodate increases in population growth, economic activity, and environmental needs. The government's decision to stop issuing water licenses led to new water users proposing water transfers to existing license holders. Bankes [4] defines a water transfer as "a formal arrangement subject to governmental review and approval by which a person (the transferee) may acquire all or part of the water right of a licensee either absolutely or for a term." However, many attempts to implement water transfers have been resisted by irrigators, whose everyday life depends on a reliable source of water. According to the Irrigation Districts Act, district irrigators have direct control over an irrigation district's ability to share water by voting in a plebiscite. Given that irrigation accounts for $71 \%$ of the province's surface water use [5], successful implementation of any water sharing mechanism will depend largely on the participation of the irrigation sector. The question therefore arises 'why are water transfers so controversial amongst irrigators in Alberta?' We specifically focus on those irrigators who oppose such attempts.

Therefore, the purpose of this study is to determine why irrigators oppose water transfers and to develop strategies for improving proposed water sharing methods. It builds on previous studies by Bjornlund et al. [5] and Lafreniere et al. [6] that explored the challenges and factors affecting irrigators' decisions to accept or reject a proposed water transfer by summarizing the main reasons why irrigators reject water transfers.

\section{Literature review}

Turton [7] discusses three alternatives for water users when their water is reduced: (1) secure more water, (2) use water more efficiently, or (3) reallocate water more equitably. Turton suggests that a reallocation of water is an ideal alternative but not without social disruptions. Opponents to water reallocation argue that transferring water out of the agricultural sector creates more dependence on importing food. Another argument is the loss of jobs within the agricultural sector [7]. Kuehne and Bjornlund [8] confirmed that irrigators of the Naomi Valley in Australia opposed water reallocation, preferring that water stayed tied to the land.

In 2007, a proposal to reallocate water for a commercial development was at the centre of Alberta's most publicized and contentious water controversy. An article published in the Calgary Herald [9] reported that the irrigation district that approved the transfer will not entertain another water rights trade in the future. In the context of the level of conflict and uncertainty among irrigators in this 
proposal, it has become clear that more knowledge is needed as to why irrigators oppose water transfers and how to facilitate future transfers.

Bjornlund et al. [5] found that irrigators in Alberta are reluctant to transfer water and instead want the saved water to stay in the district to expand irrigated production or to secure existing production during periods of drought. However, successful transfers have occurred. This result merits additional research to determine why some transfers succeed and other fail [10].

In the past, research studies on decision making in the irrigation sector assumed irrigators were homogeneous in nature and primarily driven by financial incentives (e.g. [11]) and as a result, failed to explain and predict the irrigator's reaction to water problems [12]. More recently, however, studies have demonstrated the heterogeneous nature of the irrigation sector by classifying water users according to their behavior (e.g. [8, 12]) and familiarity to water issues (e.g. [13]), thus helping policy makers to more accurately target irrigators when planning for significant changes [8]. Overall, irrigator responses to proposed water strategies are influenced by not only financial incentives but also risk, leisure time, management complexity [14], local production conditions, output and input prices, and individual characteristics of the irrigator, such as goals, debt situations and family situations [5]. This research will expand on previous studies that segment irrigators by investigating whether irrigators that oppose water transfers can be segmented by their level of opposition to water transfers, and what motivations and attitudes influence their decision to reject a proposed water transfer.

\section{Methodology}

This study was part of a larger investigation of the factors contributing to successful water transfer proposals. The main questionnaire was administered on telephone by a third-party research agency. Survey respondents were randomly selected from a list of phone numbers that the researchers thought might belong to an irrigator. Screening questions ensured that the respondent was a district irrigator and above 18 years of age. Potential respondents were offered an entry in a draw for a $\$ 500$ prize. There were 980 respondents that qualified for the survey. Of those who qualified, 275 district irrigators completed the survey $(28 \%$ response rate). The survey took approximately 36 minutes and was audio recorded.

The questionnaire investigated among irrigators against water transfers: (1) why they oppose water transfers, (2) whether they differ by motivations towards water transfers, and (3) what is their demographic profile. Based on trade-off analysis (also known as a conjoint analysis), researchers segmented respondents into 3 groups: (1) irrigators "strongly against" water transfers, (2) irrigators "moderately opposed" to water transfers, and (3) irrigators who are open to water transfers. Sixteen scenarios describing possible water transfer proposals (varying in sale price, personal benefit, water savings environmental efficiency, type of buyer, and government involvement) were manipulated to perform a trade-off analysis. Respondents evaluated each scenario on a scale from 0 to 20,0 being 
"extremely unlikely" and 20 being "extremely likely", that they would vote yes to the proposed water transfer. Removing respondents with a low goodness-of fit score reduced the usable sample to 254 respondents.

Respondents who reported to consistently unlikely vote yes to water transfers (all 0s or 1s) were classified as "strongly against" water transfers $(\mathrm{N}=46)$. Respondent that scored the scenario based on the variables described in the scenario, but never provided a score above 10, were categorized as "moderately opposed" to water transfers $(\mathrm{N}=55)$. Finally, respondents that based their score on the factors present in each scenario were categorized as "favourable" to water transfers $(\mathrm{N}=153)$. Favourable members were removed from the qualitative analysis because their responses were beyond the scope of this research, but their demographic and attitudinal scores were retained for later comparison. This segmentation process was selected because it enabled the researchers to discriminate between irrigators who strongly oppose water transfers and irrigators who are moderately opposed.

Qualitative questions in the survey, gave irrigators an opportunity to express why they opposed water transfers. Emerging themes were identified by analyzing individual interview transcripts and then by comparing the themes from other interview transcripts. The researcher then took all observations and subjected them to collective scrutiny according to what the literature says ought to be there, how the decision making process is constituted in the researcher's experience, and what was discussed in the interview [15].

\section{Results}

Three segments emerged and varied significantly based on demographic and attitudinal variables (Table 1). Favourable irrigators represented the biggest segment (60 percent). This segment has a college or university degree, 11-20 years of experience irrigating in Alberta, belongs to the 46-55 age category, and shows the most satisfaction towards their irrigation district. For more information on how the factors described in each scenario affected the decision making process of this segment, see [16].

Irrigators moderately opposed to water transfers accounted for over $21 \%$ of the sample. They showed very little preference towards any of the factors that define a water transfer. The majority in this segment reported 21-30 years of experience irrigating in Alberta and completing college or university. These irrigators felt that their district was run by a few big interests looking out for themselves and reported the lowest level of satisfaction with their district.

Irrigators that were strongly opposed to water transfer showed no preference towards any water transfer scenario, and they posited that water should not be sold under any circumstances. The majority in this segment reported completing high school and fell in the 56-65 year old category. This group had the most experience (40 years or more) irrigating in Alberta. They showed the lowest preference to water transfers in general. 
Table 1: Demographic and attitudinal variables.

\begin{tabular}{|c|c|c|c|c|}
\hline Segment & $\begin{array}{l}\text { Strongly } \\
\text { Opposed to } \\
\text { Water } \\
\text { Transfers } \\
\end{array}$ & $\begin{array}{l}\text { Moderately } \\
\text { Opposed to } \\
\text { Water } \\
\text { Transfers } \\
\end{array}$ & $\begin{array}{l}\text { Favourable } \\
\text { Water } \\
\text { Transfers } \\
\end{array}$ & $\begin{array}{l}\text { One-way } \\
\text { ANOVA } \\
\text { result* }\end{array}$ \\
\hline $\mathrm{N}$ & 46 & 55 & 153 & \\
\hline \multicolumn{5}{|l|}{ Demographics } \\
\hline $\mathrm{Age}^{\mathrm{e}}$ & $56-65$ & $46-55$ & $46-55$ & $0.011^{\mathrm{f}}$ \\
\hline Education $^{\mathrm{e}}$ & $\begin{array}{l}\text { Completed } \\
\text { High } \\
\text { School }^{\mathrm{a}}\end{array}$ & $\begin{array}{l}\text { Completed } \\
\text { College/ } \\
\text { University }\end{array}$ & $\begin{array}{l}\text { Completed } \\
\text { College/ } \\
\text { University }^{\mathrm{b}}\end{array}$ & 0.071 \\
\hline $\begin{array}{l}\text { Experience } \\
\text { irrigating in } \\
\text { Alberta }^{\mathrm{e}}\end{array}$ & $\begin{array}{l}40 \text { years or } \\
\text { more }\end{array}$ & $\begin{array}{l}21-30 \\
\text { years }\end{array}$ & $11-20$ years & 0.011 \\
\hline $\begin{array}{l}\text { What do you think of } \\
\text { Water Transfers in } \\
\text { general }^{\text {c }}\end{array}$ & 3.1 & 3.14 & 3.27 & 0.02 \\
\hline $\begin{array}{l}\text { The degree to which } \\
\text { you find your district } \\
\text { satisfactory }\end{array}$ & 3.8 & 3.72 & 3.88 & $0.042^{\mathrm{g}}$ \\
\hline $\begin{array}{l}\text { District is run by a few } \\
\text { big interests looking } \\
\text { out for themselves }\end{array}$ & 2.34 & 2.61 & 2.43 & 0.02 \\
\hline \multicolumn{5}{|c|}{$\begin{array}{l}\text { * Significantly different at the } 0.05 \text { level. } \\
\text { a, b Difference in alphabetical superscripts signifies significant mean difference }(\mathrm{p}<.05) \\
{ }^{c} 1-5 \text { Scale } \\
{ }^{d} \text { Mode score shown } \\
{ }^{e} p<.05 \\
{ }^{f} \text { F-Value reported }\end{array}$} \\
\hline
\end{tabular}

\subsection{Open-ended question results}

Some quotations from the open-ended questions which illustrate the similarities and differences between the two segments opposed to water transfer are listed below.

\subsubsection{Similarities between irrigators strongly opposed water transfers and moderately opposed to water transfers}

Both segments suggested that water is too valuable to sell. Irrigators in the "strongly against" water transfers segment felt they needed the water. As one irrigator stated, "in the future, we will need water. I don't think we should sell it out of our district for any amount of money." This group of irrigators often compared water to money in the bank. As one irrigator stated, "water is like money in the bank, and you never give your money away. Without water, we will never survive." 
An irrigator "moderately opposed" to water transfers described a similar feeling, "If we sell our water and then run out of water, we are out of business." Many irrigators in this segment worried about the supply of water. As one stated, "I am concerned from past experience when there has been inadequate snowfall in the mountains to supply irrigation water to us. It's most difficult for me to give up any irrigable water at all, which in the future may jeopardize our operation due to the lack of water." Similarly, another irrigator in this segment expressed concern about the amount of future water available. He stated, "if the climatologists are right, we are going to have less and less water to work with."

Many irrigators in both segments also felt that expanding their district so they can accept more water users was a better solution than transferring water outside the district. In this context, a district expansion is when new water users are able to join the district and use a specified amount of the district's water. As one irrigator who was strongly opposed to water transfers stated, "I would like to see an expansion of the districts. If we gain any water through improved efficiencies, let the district expand themselves at a reasonable value for water rights. That way our efficiencies would benefit us rather than another area." Another irrigator from this segment felt that to choose a water sharing method besides expansion would hurt them. He stated, "I feel dividing up the licences will hurt us. If someone needs water, buy the land in the district that already has the rights."

Many irrigators "moderately opposed" to water transfers also felt expansion was a better solution. As one stated, "there is room for expansion in my district. So if people ask me to sell my water, I am not in favor. Even if we shared water to a municipality within my district, I'd be in favor, but once you ask me to sell it outside my district, I'm against it." Similar sentiment is voiced by another irrigator moderately opposed to water transfers, "instead of water transfers, we should expand our own district."

Bjornlund et al. [5] report similar responses. They found that irrigators opposed to water transfers believe water should stay in the district to expand irrigated production or to secure existing production during periods of drought.

\subsubsection{Opinions of irrigators "strongly opposed" to water transfers}

The majority of irrigators in this segment reported why they would never vote in favour of a water transfer was because water is a limited resource and they need it to maintain their lifestyle. One irrigator expressed how people often forget that water is limited. He stated that "in most years, there's plenty of water to go around. It seems we forget what it's like to have no water." Many irrigators remember a time when water was rationed. As one stated, "we do not have enough water in our district. We have been monitored in the past because of hot, dry conditions." Some irrigators in this segment do not even have enough water to maximize production on their land already. As one stated, "I'm sitting on 250 acres of dry land right in the middle of the irrigation district, and I can't get water rights because there isn't any. My district say there isn't any extra water, so why would I want the district to sell water rights?" They feel that they are 
already efficient but that might not be enough in the future. One stated, "we are pretty efficient, and we account for every drop of water."

Aside from expansion, irrigators "strongly opposed" to water transfers reported that they would only share water if it was leased temporarily or for an emergency. As one irrigator reflected on possible solutions, he stated: "you do not sell your water licenses. You can lease a water license for 20 years to get upgrade." Another irrigator described when it might be okay to temporarily supply water by stating, "if we had sufficient water to meet the needs of the irrigators and the prospective users of water, then we could temporarily supply water, provided it is not easier to get it somewhere else." Talking about emergency situations, one irrigator said, "in the event of an emergency, on a one time basis, I could see diverting water to help someone."

A small number of irrigators expressed that they didn't have enough knowledge about water transfers to make an informed decision. As one stated, "I'm not really informed so I can only talk about what I've read. I'd like to be more informed." Another irrigator felt that the district needs to better inform new members. He stated, "it would be nice if the district would get involved with the new people and explained how this process worked because we had no idea we even had a vote."

\subsubsection{Opinions of irrigators "moderately opposed" to water transfers}

Irrigators "moderately opposed" to water transfers based their decision to reject a proposed water transfer on factors such as the type of buyer and environmental or communal gains. Many irrigators in this segment reported that only irrigators should get their water. As one stated, "I disagree with anyone but irrigators getting water from our irrigation district." Another expressed that they would much rather see their water go to other irrigators than to a municipality. When asked why they preferred other irrigators as the buyer in a proposed water transfer, they mentioned a need to take care of each other. As one stated, "water is going to be a very big political issue down the road, and we need to be looking after our own."

Many irrigators in this segment indicated that water transfers may negatively affect the whole community, and any decision about water must be mutually beneficial to the whole community. As one stated, "we must arrive at a consensus that meets the needs of as many people as possible." These irrigators were not only concerned with their current community, but future generations as well. One irrigator described the need to help future generations in the following way: "if district managers decide to sell a part of our water, it's going to affect the whole district. Whoever is taking care of my land in the future will wonder who made that stupid decision to sell water. We are already seeing some pretty significant changes. We need to carefully explore future consequences so we don't have any regrets." They were also concerned about putting pressure on the food supply of a growing community. One stated, "it's okay that more people and industries are coming into the area, but we have to be careful. If we don't have farmland and irrigation, we won't have enough food.' 
Other irrigators in this segment reported that they were primarily concerned with how the water transfer would negatively affect their ecosystem and efficiencies. As one irrigator stated, "the district has to be careful removing water. If you transfer water that is upstream, then you are changing the ecosystem downstream." They even indicated that they would consider selling water for important environmental causes. As one stated, "we should not sell our water unless there is an environmental need that would be good for Alberta or future generations. If the water was for people, animals, insects or anything for the ecosystem, then it would be okay." The irrigators "moderately opposed" irrigators insist that water must always be used efficiently. As one stated, "I don't want to use our water inefficiently. If the water can be supplied more efficiently by another source, then I would vote no."

\section{Discussion and conclusions}

The results from the survey show that there are many reasons for irrigators to oppose a proposed water transfer. The research suggests that irrigators against water transfers can be segmented into two groups based on their motivations and attitudes. Initial results suggest that it would be worthwhile continuing to develop a typology of irrigators based on their degree of opposition to water transfers. Further analysis should be conducted to control for irrigator or farm characteristics.

It could be expected that the outcome of this research would be useful for those formulating a marketing plan targeting farmers opposed to water transfers, especially when there is a need of cooperation over a contentious issue. The two segments explored in this study could be targeted with different campaigns. First, managers could take little steps by eliminating the concerns from the uninformed group. Irrigators "strongly opposed" to water transfers change their opinion if they perceive a high degree of urgency. Irrigators "moderately opposed" to water transfers may approve a water transfer proposal that emphasised communal or environmental needs. Managers could also increase support by introducing alternative water sharing, such as expanding districts or transferring water only in the event of an emergency.

This model also expands on Turton's [7] discussion regarding why water transfers may be socially unfavorable. Turton argued that people with nationalistic views may be against importing food from other countries, and others will oppose the loss of jobs in the agriculture industry. Our study found an additional reason of potential negative influence on the ecosystem and water efficiencies.

In conclusion, initial research suggests that segmenting irrigators by whether or not they consider any factors involved in a proposed water transfer could be an effective way to differentiate motivations behind an irrigator's decision to oppose a transfer. While these irrigators share some similarities, such as the belief that water is too valuable and district expansions are more favourable than permanent water transfers, irrigators "strongly opposed" to water transfer won't consider any factor in the water transfer proposal, while irrigators "moderately 
opposed" to water transfers often use personal, communal, and environmental consequences as a reason to reject a proposed transfer.

\section{Acknowledgement}

This research is part of a larger project funded by Alberta Innovates: Energy and Environment Solutions.

\section{References}

[1] Conference Board of Canada, Going with the flow? Evolving water allocations and the potential and limits of water markets in Canada, report, prepared by Brandes, O., Nowlan, L., Paris, K. and Wilts, R., 2008.

[2] Bjornlund, H. Nicol. L. and Klein, K. K., The adoption of improved irrigation technology and management practices - a study of two irrigation districts in Alberta, Canada, Agricultural Water Management, 95, pp. 121131, 2009.

[3] Alberta Environment, Background information for public consultation on the SSRB's draft water management plan, Edmonton, Alberta: Author, 2005.

[4] Bankes, N., The legal framework in Alberta for acquiring water entitlements from existing users. Alberta Law Review, 4(2), pp. 323-376, 2006.

[5] Bjornlund, H., Nicol, L. and Klein, K. K., Challenges in implementing economic instruments to manage irrigation water on farms in southern Alberta, Agricultural Water Management, 92(3), pp. 131-141, 2007.

[6] Lafreniere, K. C., Deshpande S. and Bjornlund, H., Extending stakeholder theory to promote resource management initiatives to key stakeholders: A case study of water transfers in Alberta, Canada. Journal of Environmental Management, under review (round 2).

[7] Turton, A., Water scarcity and social adaptive capacity, $M E W R E W$ Occasional paper no.9. 1999, Water issues study group - School of Oriental and African Studies: London, p. 1-40.

[8] Kuehne, G. and Bjornlund, H., "Custodians" or "Investors" - classifying irrigators in Australia's Namoi Valley. Sustainable Irrigation Management Technologies and Policies, eds. G. Lorenzini and C.A. Brebbia, WIT Press: Southampton, pp. 225-236, 2006.

[9] Calgary Herald, Balzac track gets its water, Aug 3, 2007, online.

[10] [Matthews, O., Water reallocation in the west: an "inconvenient" truth? Journal of Contemporary Water Research and Education, 144, pp. 1-4, 2010.

[11] Vandermersch, M. and Mathijs, E. Do management profiles matter? An analysis of Belgian dairy farmers. Contributed paper, $10^{\text {th }}$ Congress of European Association of Agricultural economists, Zaragoza, p. 1-14, 2002. 
[12] Maybery, D., Crase, L. and Gullifer, C., Categorising farming values as economic, conservation and lifestyle. Journal of Economic Psychology, 26, pp. 59-72, 2005.

[13] Thorvaldson, J., Pritchett, J. and Goemans, C., Western households' water knowledge, preferences, and willingness to pay, Canadian Journal of Agricultural Economics, 58, pp. 497-514, 2010.

[14] Gómez-Limón, J. A. and Riesgo, L., Water pricing: Analysis of differential impacts on heterogeneous farmers. Water Resources Research, 40, pp. 112, 2004.

[15] McCracken, G., The long interview, SAGE Publications: New York, 1998.

[16] Lafreniere, K., Deshpande, S. and Bjornlund, H., Segmenting and targeting irrigators' preferences of proposed water transfers, Society and Natural Resources, submitted for review. 